\title{
Pragmatic and Permeable Egalitarianism:
}

\author{
Exploring Social Life in Norwegian Prisons
}

Kristian Mjåland, Associate Professor, University of Agder, Norway and Visiting Scholar, University of Cambridge, UK \&

Julie Laursen, Assistant Professor, University of Copenhagen and Research Associate, University of Cambridge, UK

\begin{abstract}
The social world of prisons is typically described as hierarchical in the prison sociological literature where offence type, displays of (hegemonic) masculinity and involvement in the informal economy impact prisoners' social standing. Based on fieldwork and interviews ( $N=181)$ with men and women in seven different Norwegian prisons, this article describes prisoner cultures where such hierarchies were either absent or of little significance. Rather than pointing out differences in status and standing, the prisoners interviewed tended to insist that they were equal and the same. In order to make sense of this finding, which contrasts dominant accounts in the prison sociological literature, the article engages with scholarship on the role and roots of egalitarianism in Norwegian society. Organizing the discussion around the concepts of 'egalitarian permeability', 'pragmatic egalitarianism' and 'social labour', the article argues that the egalitarian culture of Norwegian (open) prisons is shaped by norms in the wider Norwegian society and the pragmatic choices prisoners make to cope socially in prison everyday life.
\end{abstract}

\begin{abstract}
I fengselssosiologien blir fengselets sosiale liv ofte beskrevet som hierarkisk. Studier har vist at lovbruddstype, (hegemonisk) maskulinitet og involvering i den illegale økonomien har betydning for fangenes sosiale status og posisjon. Basert på feltarbeid og intervju $(\mathrm{N}=181$ ) med menn og kvinner i syv norske fengsler viser denne artikkelen at slike hierarki var enten fraværende eller av liten betydning. I stedet for å påpeke forskjeller i status og posisjon vektla fangene som ble intervjuet ofte at de var like og likeverdige. For å forstå dette forskningsfunnet, som bryter med beskrivelser i deler av forskningslitteraturen, henter artikkelen inspirasjon fra forskning om den norske egalitære kulturen. Ved å organisere diskusjonen om begrepene 'egalitarian permeability, 'pragmatic egalitarianism' og 'social
\end{abstract}


labour' argumenterer vi for at den egalitære kulturen i norske (åpne) fengsler er formet av normer og verdier i det norske samfunnet, og av de pragmatiske valgene fangene gjør for å håndtere fengselshverdagen best mulig.

\author{
Key words \\ Prisons - Social Relationships - Egalitarianism - Hierarchy
}

\title{
Introduction
}

'Entering prison means having to join a compulsory social community that is commonly hierarchical and likely to be underpinned by core institutional and group values linked to gender, class, ethnicity, and age, sometimes referred to as a normative prison code' (de Viggani 2012, page 272).

The social world of prisoners is frequently described as hierarchical (Sykes 1958; Goffman 1961; Cohen \& Taylor 1972; Sim 1994; Toch 1998; Treadwell, Gooch \& Barkham-Perry 2018; Ugelvik 2014b). Prisoners' placement in this hierarchical world might depend on the offence they have committed, their ethnicity, membership in organized gangs or groups, involvement in the sub-rosa prison economy, or the degree to which they conform to masculine norms. While we do not want to question the accuracy of such descriptions of prisoner social organization, our approach in this article is to problematize the tendency to view prison social life as inevitably and inherently hierarchical.

We justify this approach by pointing to some shortcomings in the literature on prison social life. Firstly, there has been a recent call for more nuanced examinations of emotional flows and social relationships between male prisoners (Crewe 2014; Laws \& Lieber 2020; Stevens 2013). Laws and Lieber (2020, page 3) argue that even though some studies do address the issue of 'soft' values in prisons, such as kindness, there has been a tendency to analyse these through an individualised and instrumental lens (see Jewkes 2005; Ugelvik 2014a). Following Laws and Lieber (2020, page 3), then, there is a need for studies that «complicate linear depictions of prison life that are emotionally stolid». Secondly, most of the existing literature on prison social life stems from an Anglophone context (but see Laursen 2017; Minke 2012; Mjåland 2014; Ugelvik 2014b). As the literature on 'Nordic exceptionalism' has highlighted, Nordic penal policy and practices diverge from those in Anglophone countries in important ways, most notably by having lower incarceration rates and more humane prison conditions (Pratt 2008; Pratt \& Eriksson 2013, but see Ugelvik \& Dullum 2012 and Smith \& Ugelvik 2017 for accounts who critique and nuance the 'Nordic exceptionalism' thesis). However, few studies have so far explored the relation between 'exceptionally humane' prison conditions and the social organization of prisoners (but see Skarbek 2020 for an interesting comparative 
approach). Thirdly, most studies of prisoner social life are conducted in high security prisons (but see Shammas 2014; 2015a, b). While this is understandable, given the extensive use of and reliance on high security imprisonment in most Anglophone jurisdictions, it is nonetheless regrettable. Low security prisons ('open prisons') account for a substantial proportion of the operational capacity in the Nordic countries. ${ }^{1}$ Furthermore, the 'normality principle' is a guiding philosophy of Nordic penality, which, at least in theory, has a particular significance in low security prisons: The normality principle is meant to ensure that all measures and hindrances that are not a necessary part of depriving prisoners of their freedom are to be removed, in order to make life on the inside resemble life on the outside as much as possible (Balvig 2005, page 178; see also Engbo 2017). While research has explored the significance of this principle for material conditions (e.g. Engbo \& Smith 2012), few studies have explored how the aim of creating more 'normal' penal environments affect relational dynamics among prisoners. The aim of this article, then, is to help address these shortcomings in the literature, by offering an analysis of the norms and values that characterise social life in Norwegian high and low security prisons.

Based on qualitative interview data with male and female prisoners in seven Norwegian prisons, we describe prisoner cultures where hierarchies based on offence type or masculine displays were either absent or of little significance. Rather than pointing out differences in status and standing between prisoners, our interviewees tended to insist that they were equal and the same. In order to make sense of this finding, which contrasts dominant accounts in the prison sociological literature, we engage with scholarship on the role and roots of egalitarianism in Norwegian society (Bendixen, Bringslid \& Vike 2018; Gullestad 1984; Sakslind \& Skarpenes 2014; Sakslind, Skarpenes \& Hestholm 2018). Organizing the discussion around the concepts of 'egalitarian permeability'(how societal values of equality permeate prison walls), 'pragmatic egalitarianism' (how egalitarianism is pragmatically performed) and 'social labour' (the efforts mobilized to maintain an egalitarian prison environment), we will argue that the egalitarian culture of Norwegian (open) prisons are shaped by norms in the wider Norwegian society and the pragmatic choices prisoners make in order to cope socially in prison everyday life.

\section{Literature review}

Descriptions of prisoner hierarchies are rife in the literature. David Skarbek (2014) links hierarchies to race-based prison gangs, where experienced gang-leaders are at the top. Others, including Jewkes (2005), Michalski

1. Around $30 \%$ of prisoners were held in open prisons in Norway, Denmark, Finland and Iceland in 2015. In Sweden a significantly lower proportion (approximately $12 \%$ of prisoners) were held in open prisons that year (Lappi-Seppälä, 2020, page 37). 
(2017), and Ugelvik (2014a,b), argue that hierarchies in prison are shaped by (hegemonic) masculine norms, where «capacity for 'masculine dominance', toughness, physical prowess, [and] aggressiveness» (Michalski 2017, page 50) are key sources of respect and status, hence the prisoners who epitomize masculinity stand at the top (Stanko 2001 in Evans \& Wallace 2008, page 488). A number of studies have found that hierarchies depend upon offence type: the robber or the 'business men' sit much more comfortably in the prison hierarchy than the sex offender (Treadwell et al. 2018). Studies from Nordic prisons have also described hierarchical prison cultures, emphasising, amongst others, the role of gendered norms and values (Lindberg 2005; Mathiassen 2017; Ugelvik 2014b), ethnicity (Haller \& Kolind 2018) and socialization into prison subcultures (Minke 2012, 2014). These hierarchies tend to be described as rather static and permanent with few descriptions of how power flows between categories of prisoners and is produced and reproduced amongst them. However, a recent study by Kreager et al. (2017), using a mixed methods approach to study prisoner hierarchies in a US 'good behaviour' prison unit, intervened in this literature with somewhat contrasting findings. They found that in this specific unit 'old-heads' were at the top of the hierarchy (see also de Viggiani 2012, page 281). Older prisoners, who had been on the wing for long, and who used their power and influence for the common good, were the most respected. Other sources of status, such as offence type, criminal networks, ethnicity and physical strength, were far less important. This finding is significant, because it effectively warns against seeing prisoner hierarchies, and the sources they rely upon, as an inherent property of prisons, as a nearly universal phenomenon. Furthermore, this finding points to the fact that prison social organization must be studied by attending carefully to context.

Context can be institutional, as in Kreager et al.'s study, where they argue that the classification ('good behaviour') of the unit they studied incentivized pro-social norms and behaviour. This context can also be cultural; hence, the norms that shape prisoner organisation are influenced by 'cultural configurations' in larger society. A cultural context of relevance for the analysis that follows is the nature and character of egalitarianism in Norwegian society. According to Bendixen et al., egalitarianism in Scandinavia has been explored through different analytical strategies, but one important distinction can be drawn between those who see egalitarianism as «an unintended effect of historical contingencies» (Bendixen et al. 2018, page 5), where egalitarian values over time became embedded in institutional practices and are thus seen as relatively stable cultural phenomenon, and those who see egalitarian values and cultures as resources and constraints that people navigate and make us of in everyday social interaction (ibid., page 4) - a line of inquiry resembling Swidlers (1986) notion of cultural 'tool kits'.

The first perspective chimes with how John Pratt (2008, page 120) sees Nordic penality as an outcome of egalitarian policies, structures, values and practices, with deep historical roots. Pratt, then, treats egalitarianism as a 
cultural 'fact', produced over time, and embedded in institutional practices. Such a take on egalitarianism has affinity with how Norwegian sociologist Ove Skarpenes and colleagues understand it. They claim that «[t]he pervasive presence of egalitarian values in Norwegian society is a rather uncontroversial assertion» (Skarpenes \& Sakslind 2010, page 238, fn. 7). One of their central arguments concern the importance of morality in the Norwegian egalitarian culture. They show how their interviewees, members of the upper middle class, refrain from establishing hierarchies of taste or worth, and argue that this is an indication of the continued relevance of 'puritanical Christianity' (Sakslind et al. 2018, page 197), in which judging people's tastes and practices are seen as immoral acts of self-assertion. Thus, egalitarianism is upheld as a key cultural value because claiming superiority breaches an important moral code. Such an approach invites us to study egalitarian permeability. Norwegian prison walls and fences are porous, particularly so in open prisons (Shammas 2015b). If egalitarianism is a core value in Norwegian mainstream society, we would then expect egalitarian values to bleed into the Norwegian prisons and shape the nature of social relationships in these institutions (Baer \& Ravneberg 2008; Shammas 2015a, page 7).

The second approach is closely associated with the works of Norwegian anthropologist Marianne Gullestad (1984). Her concept of 'egalitarian individualism' suggests that 'egalitarianism' is not a cultural 'thing', but rather a resource or constraint that guide everyday social interaction. According to Bendixen et al. (2018, page 4), Gullestad emphasised that «the dominant code of behaviour she had observed in a variety of social contexts where equality in status was ritually emphasized, was a pragmatic one». People perform equality, or sameness which was the term Gullestad preferred, in situations where 'objective' status differences interferes or disrupt social interaction. A study of egalitarian practices in prison would then involve an exploration of how people pragmatically mobilize values or repertoires of equality in the presence of inequality.

\section{Methodology}

This paper is based on data from a large comparative study of penal policymaking and prisoner experiences in England \& Wales and Norway. While the overall research project comprised several sub-studies, ${ }^{2}$ we draw on a longitudinal study of male and female prisoners' experiences of entry into and release from prison, in which we conducted 181 interviews in seven Norwegian prisons. Two prisons in our sample were categorised as 'open' (Bjørgvin and Søndre Vestfold, Avdeling Berg) and three were 'closed', but had open wings

2. For a more detailed presentation of the research project, see https://www.compen.crim.cam.ac.uk/. 
located outside of the prison (Bergen, Bredtveit and Arendal). ${ }^{3}$ We aimed to follow our interviewees longitudinally by interviewing them shortly after their entry into prison, just before their release and finally within three months post-release. In order to gain a broader and more contextualised understanding of social life in these institutions, we also did participant observation, which meant we 'hung out', played table tennis and volleyball, participated in the daily life on the wings, in the workplaces and in communal facilities such as dining halls and outdoor spaces. These observations, documented in extensive field-notes, inform this analysis although quotes from interviews are our main data source.

All interviews were conducted in small, private rooms off the wings, lasted between 1-3 hours, and were transcribed and then translated to English. The interviews were coded thematically drawing on a theoretical framework entailing the 'depth, weight, tightness and breadth' of imprisonment (see Crewe 2011) and using Nvivo software. We asked detailed questions about social relationships in the interviews such as 1) the nature of prisoners' relationships with each other and staff, 2) who they spent time with and who they preferred not to be around, who they respected and liked, and 3) where they would place themselves and others in a prisoner hierarchy, if such a thing existed.

This article develops an analysis of some aspects of social life in the institutions in our sample. More specifically, we follow an abductive research strategy (Blaike 2000, page 100), where we, based on some initial observations about the relative 'ordinariness' of everyday social life in particularly the open prisons, and the apparent insignificance of prisoner hierarchies in both high and low security prisons, systematically went on to explore these themes in our field- and deskwork. When conducting the interviews, we encouraged our interviewees to describe in as much detail as possible the nature of their relationships with other prisoners. When reading interview transcripts, and interview content coded at relevant nodes (e.g. 'friendships', 'hierarchies', 'other people's offenses', 'virtues'), we explored our interviewees' descriptions of their social worlds across the prisons, wings and units represented in the study. Although there are important differences in the relational dynamics between the different fieldwork sites, the egalitarian culture we describe in the analysis below was nonetheless present in all prisons in our sample, yet more so in the open establishments. We have nonetheless chosen to emphasise the common patterns in this article, describing and discussing the egalitarian nature of prison social life as represented in our data, at the expense of more detailed explorations of differences between prisons and wings. While the risk of this analytical strategy is the lack of attention to nuance, the benefit is that it allows for a more theoretically informed analysis of one particularly significant and intriguing feature of prison social life.

3. The two 'pure' high security prisons in our sample for this sub study was Halden and Ullersmo. 
In the section below, we first describe the egalitarian nature of prison social life that we identified through our analysis of our data. We then move on to discuss this main finding of the article, by exploring the degree to which egalitarian orientations in Norwegian society permeates prison walls ('egalitarian permeability'), by considering egalitarianism as pragmatically performed ('pragmatic egalitarianism') and by attending to the intense 'social labour' required to produce and maintain egalitarian social climates in prison.

\section{Egalitarian prison culture}

The literature reviewed above implies that it may be necessary to conform to hegemonic masculine ideals in order to ensure «emotional, psychological, and social survival» in prison, which entails «employing strategies to mask self-perceived weaknesses or vulnerability and to attain status and legitimacy» (de Viggiani 2012, page 272). Such hegemonic masculine ideals featured in our material as well, but mainly through interviewees' expectations of what prison life would be like. For instance, many interviewees described how they were feeling anxious when they were awaiting their prison sentence, especially in relations to meeting and interacting with other prisoners. Partly based on descriptions of prison social life in popular culture (Evans \& Wallace 2008, page 488), they expected to find a tense social atmosphere, clear-cut hierarchies and a somewhat ruthless culture. Gerhard, serving a sentence in a high security prison, claimed younger (as found by de Viggiani 2012, page 279) and foreign prisoners to be particularly prone to be prepared for the 'worst' when entering prison:

\footnotetext{
A lot of the younger inmates who are foreigners think that they are going into an American style prison. They usually realise after a month or two that it is not like that. They tend to be a bit tough in the beginning. Then they understand how things work (Gerhard, Bergen).
}

Although prisoners might arrive at the prison, thinking they need to 'demonstrate emotional and physical fortitude and suppress signs of weakness, in order to avoid exploitation' (Crewe, Hulley \& Wright, page 265; Jewkes 2005; De Viggani 2012), our interviewees described the many ways new prisoners were 'managed' and shown which values count in these institution. These values, which shaped prison social life, shared a common egalitarian orientation.

One way to get a sense of these values and normative underpinnings of social life in prisons is by attending carefully to how prisoners themselves describe social relationships during incarceration, including the metaphors they use. Kasper, an elderly man convicted of a sexual offence served three months in a small open prison. He was terrified when he first got to the prison, and self-isolated in his room for almost a month. Gradually, he developed 
positive and supportive relationships with a few of the other men, and in the post-release interview he went as far as to say that he missed the prison:

What about the prison did you feel that you missed?

The community and the friendships with other people in the same boat. The same boat, yes. In prison for different things. Which, that is what I missed (Kasper, Arendal).

Kasper was far from the only of our interviewees who spoke warmly about inclusionary social communities in the post-release interviews, and neither was he the only one to use the egalitarian metaphor of being 'in the same boat'. Indeed, this metaphor was used to describe social life in a variety of prisons, wings, and units in our study. Asle, serving a sentence in a different open unit in Arendal prison, put it like this:

It's the same thing I try and say to the new people coming in here now as well [ ... ]: «just remember in here we are all the same», «we are all the same». If you are a captain steering the ship, if you're a manager or you're far down the ladder and have been a drug addict for the last thirty years or whatever, we are all in the same boat in here, we are all the same.

What do you actually mean by that?

[ ... ] Some of us have done the wrong thing, but if you reverse the tape a bit, we were all normal human beings. I feel that in here there is nobody who is better than anyone else (Asle, Arendal)

The insistence on 'being in the same boat' has a moral undertone - it involves a command of not judging others and not thinking that anyone, including yourself, are better than others. This non-judgemental imperative is illustrative of Sakslind and Skarpenes' (2014, page 324) observation about the significance of 'equality and solidarity' in 'Norwegian morality'. However, the metaphor was used to highlight other aspects of egalitarianism as well. Benedicte used it to describe the social life at Bredtveit, a women's prison, highlighting a kind of solidarity between the women which served to diminish the significance of people's convictions:

In prison everyone is the same; we have different convictions, but we are in the same boat. [ ... ] One is here for murder, I'm here for theft, one is here for using a fake passport, but all the ladies are in the same boat (Benedicte, Bredtveit).

While Benedicte was one of our interviewees who most strongly emphasised the irrelevance of peoples' convictions for their worth and social standing, it was certainly a key theme in all the prisons in our study (which will be discussed in more detail below).

A final aspect of egalitarianism was introduced by Kurt, who used the boat metaphor to argue that the status prisoners enjoyed outside in the community was of little significance within the prison: 
But would you say - is there a kind of - I mean, is there some kind of solidarity or loyalty between inmates here?

[ ... ] We're in the same boat, the whole gang and that sort of thing. So it's the way it is outside. You get along with some and not with others. [ ... ] There's no difference between us. No one cares about how big you are in the outside world or anything like that (Kurt, Halden).

The quote is interesting because it alerts us to two comparative benchmarks: Not only does Kurt's 'denial of difference' (Shammas, 2015a) describe an egalitarian prisoner community which contrasts accounts in the prison sociological literature reviewed above, but he also claims that social dynamics in the prison equals those in Norwegian society at large ('you get along with some and not with others'). This latter point echoes Shammas findings from his study of an open Norwegian prison, where he argues that 'personal suitability, not ethnic or national origins, was prioritized selecting one's companions' (Shammas 2015a, page 7). In the prisons in our study, prisoners would quite consistently tell us that personal interests, 'chemistry' and suitability were far more important than ethnic origins and offence type when choosing whom to befriend and hang out with.

The individual decisions prisoners make about who they spend time with have aggregate effects on the social organization of prison life. Our interviewees, particularly so in the open prisons, described a social world organized by groups, not by 'gangs', and with community, not rivalry, between them:

But there is a very good sense of community. But all the groups have a good sense of community too. So there's not, nothing, no monkey business, luckily (Sindre, Bjørvin).

This is echoed in Erika's description from the women's prison Bredtveit. She claimed there were 'cliques' in her wing, split between the foreign nationals, the women with long sentences, and the young, but in her opinion, they all got along:

[ ... ] It's more like friend groups in high school. That's what it reminds me of a bit. A lot of women in one place, that's how it ends up being (Erika, Bredtveit).

Importantly, we are not claiming that hierarchies are completely absent in social life in Norwegian prisons. While most of our interviewees would describe the social atmosphere in the open prisons in positive terms, power dynamics shaped social life, although in subtle ways. Hjalmar, for instance, serving a short sentence in the open prison Bjørgvin, claims that 'everyone has been nice to each other' in his unit, and 'we've had a really good atmosphere here the whole way through'. However, the norms of decent and kind behaviour are backed up by what he calls 'clear' instructions: 
I'm clear though. Let's say that I'm clear without making any threats, but I imply that it will get uncomfortable if one doesn't comply with the rules of the house (Hjalmar, Bjørgvin)

In some of the interviews, prisoners also described how physical strength, reputation for violence, and the type of offence mattered in terms of who enjoyed power, influence and status. Interviewees typically pointed out that it involved one or two 'alpha men' who tried to impose their will in prison everyday life.

Can you say the same about the prisoners? That there's a hierarchy or - with prisoners or? Do you experience that? Or?

I guess it's like it is outside in the normal world. You have a few alpha guys who like to take control or decide. If there's a question about what people want to watch on TV for example, then most often it's one or two who answers, and it's most often the same people all along who decide, or, yes, speak their mind the loudest at least (Emil, Bjørgvin).

In some wings, such 'alpha men' were feared, and people described walking on eggshells around them or simply avoiding them to keep out of trouble. However, most prisoners did not live in a perpetual state of fear (Laws \& Lieber 2020, page 2); to the contrary, these 'alpha men' were often ridiculed in the interview setting, and people described various ways these men are 'put down'.

There are some people who are little kings, but you just have to grab them by the ears and shake them (Gjermund, Bergen).

To summarize our argument so far, then, our main finding is that social life in the prisons in our study was characterized, to a greater or lesser extent, by an egalitarian culture. Most notably, prisoners often insisted on being equal, in a way which produced feelings of community and solidarity, and which served to neutralize the evaluative impact of prisoners (prior) social status and convictions. Prisoners socialized in groups and cliques based on personal preferences and suitability. Social life was characterized more by 'horizontal harmony' than 'vertical antagonism'. These egalitarian descriptions of social life stand in rather sharp contrast to existing accounts in the literature, yet they do resemble Shammas' (2015a) findings from his study of an open Norwegian prison. He argues that prisoners 'denial of difference' is 'the result of the unique institutional texture of both the open prison and the Norwegian prison system' (Shammas 2015a, page 5). In the remainder of this article we will try to unpack this 'institutional texture'. 


\section{Egalitarian permeability}

The historical, anthropological and sociological literature (e.g. Bendixen et al. 2018, Sakslind et al. 2018, Skarpenes \& Sakslind 2010) generally describes Norwegian society and culture as egalitarian. According to Sakslind and Skarpenes, this egalitarian orientation is even embraced by the Norwegian upper middle class, thus contributing to a distinct (middle)class culture in Norway. A distinguishing trait of this culture 'appears to be a certain humility or modesty in forms of self-presentation, aligned with an egalitarianist rejection of vertical boundaries' (Sakslind \& Skarpenes 2014, page 331). Based on their empirical analysis - interviews with a sample of 112 members of the Norwegian upper middle class - they identify two 'orders of morality' at work. ${ }^{4}$ The first is anchored in Christian humanistic values (altruism, honesty, tolerance, respect of others, brotherly love etc.), in which the Good Samaritan is the ideal type. The second is anchored in values such as equality and solidarity, in which the Socially responsible citizen is the ideal type. Members of the middle class value most the individuals who do good and care for and about the community, and they value the least those who are judgemental and egoist (ibid., page 319-325). To what extent is the egalitarian character of prison social life a reflection of these moral orders in Norwegian culture and society more broadly?

In exploring this question, we draw on the idea of the 'permeability and porousness' (Shammas 2015b, page 5) of the open Norwegian prisons. While the inside of a prison is always to some degree a reflection of the outside society where it is located, this is arguably more so for the open prisons, where the wall separating the prisoners from their communities are thinner, both symbolically and literally. Not only do open prisons have fewer and less restrictive physical security measures, they also hold many prisoners convicted of less serious offences on relatively short sentences. ${ }^{5}$ Prisoners, visitors and staff cross the boundary between inside and outside more frequently, and with less effort, than in high security prisons. The permeability of this boundary shapes social life in distinct ways.

The permeability of the open Norwegian prisons is most significantly expressed in our data in the view that social life, norms and dynamics in these prisons resemble life outside to a considerable extent. Many of our interviewees were explicit in their comparisons between outside and inside. Kurt, who we quoted above, said 'it's the way it is outside. You get along with some and not with others'. Gregor made a similar point: 'It's the same as out

4. In a follow-up study with members of the Norwegian working class, drawing on the same theoretical framework, the same orders of morality were identified, although with nuances, and supplemented by a third ideal type - the hardworking person (Skarpenes, forthcoming).

5. In $2019,63 \%$ of the unconditional prison sentences issued by the courts were of six months or less (Kriminalomsorgen 2020, page 7). 
in the community. People choose friends based on shared interests, similar ages' (Gregor, Arendal). Erika (Bredtveit), when talking about who she did not like to spend time with, said: "That's how it is on the outside, too. You don't get along equally well with everyone, you choose your friends». By emphasising the similarities in social dynamics between life inside and outside of prison, such quotes illustrate how egalitarian orientations may push through the prison wall.

Furthermore, the way our interviewees talked about who they liked and respected in the prison, and why, echoed the moral repertoires described by Sakslind and Skarpenes (2014). Responding to a question of what it takes to be liked in prison, Dina said: «You just have to be honest, nice and behave properly. With everybody» (Dina, Bredtveit). Hector, in his response to the similar question, emphasised that being sincere and truthful was most important: 'I think that's the first thing; that you're the person you want to be and are genuine with others [... ] and normal common decency[ ... ]' (Hector, Bergen). The relatively short sentences in Norwegian open prisons result in diverse and rapidly changing prison populations, which one would assume could result in fairly shallow relationships between prisoners; the flow of prisoners could simply be too high and would complicate the opportunity to create lasting, 'deep' relationship. Some of the literature on social climates in prisons does indeed argue that the shallow nature of relationships results in a need to uphold a 'facade', an attempt to 'be someone you are not' (de Viggiani 2012). To our surprise, prisoners in our study often said opposite things, namely how they needed to show 'who they really are' in a short span of time: because it was important to 'be yourself' (Kurt, Bjørgvin). 'Being yourself' is generally an often-heard trope in Norwegian prisons and our interpretation is that this reflects broader egalitarian values, in the sense that you should not pretend to be somebody you are not.

The emphasis placed on being sincere and genuine is related to the 'command' of not passing judgements. Lone says that it is «difficult to judge other people. I try not to think too much about other inmates and their cases, so I don't feel I'm any better than they are» (Lone, Bredtveit). The quote is informative, because by actively avoiding thinking about other prisoners' convictions, Lone makes it less likely that she will be breaking the norm of not judging others and seeing herself in a more positive light. This might be seen as an expression of the "humility and modesty in forms of self-presentation» that Sakslind and Skarpenes (2014, page 331) claim are at the heart of Norwegian egalitarian culture.

A blend of the 'Christian humanist' and 'socially responsible' moral orders is present in our material as well, by the frequent reference to 'reciprocal respectfulness'. This is most clearly expressed in the many quotes paraphrasing the Golden Rule, found as a maxim in Christianity and other religions: 'I treat others the way I want others to treat me, plain and simple' (Aud, Bergen). Similarly, Kurt said: «You have to treat others as you would want them to treat 
you». Lone also described how relational dynamics were shaped by a reciprocal commitment to good, nice and decent behaviour:

How would you describe your relationship with the other inmates here?

[... ] as long as you are nice and smiling and helpful, most people reciprocate and are nice in return. It's really got to do with how you behave yourself (Lone, Bredtveit).

Implied in these variations over the Golden Rule is the bridging of the two moral orders. On the one hand treating others respectfully is a (Christian humanist) virtue on its own - it is 'common decency', in prison as in the community - and on the other it is a means to ensure the collective good (social responsibility): prison life becomes more bearable if you behave nicely towards others.

\section{Pragmatic egalitarianism}

So far, we have considered egalitarianism as a set of values and orientations and argued that such values seeps through prison walls and shape the social life in Norwegian prisons in distinctive ways. Yet, as advocated by Gullestad, Norwegians insist on equality and sameness not because they are particularly virtuous, but more so because they are pragmatic. People are skillful social actors who navigate pragmatically through the normative waters of the setting. Hence, the egalitarian character of social life in prison should be seen as an ongoing negotiation by prisoners who try to overcome their imprisonment in the best possible manner.

What we have termed 'pragmatic egalitarianism' is most clearly implied in the way prisoners deal with people and offences they do not approve of. This is evident in our material in three different ways. The first is rather basic, and it involves overlooking people's convictions and only paying attention to how they behave in prison everyday life. The following quote is illustrative:

\footnotetext{
Yes, the important thing is how they treat me and how they behave in here. If they are nice and polite and they are themselves; not rude and loud mouthed, then it's okay with me. I don't care why they are here. I think that goes for most people here (Kjell-Arne, SVF Berg).
}

In our interpretation, these prisoners make a pragmatic choice to only base their evaluative judgements of their fellow prisoners based on observable behavior. By not considering what other peoples' convictions morally communicate about who they are, their everyday life in the prison becomes less complicated. What matters to them is whether people are 'nice and polite', because this have the most bearing on their day-to-day quality of life. Not passing judgements is therefore not so much about being virtuous, but more 
of a pragmatic adaptation to prison social life - what levins has described as «a form of collective coping-acceptance» (2017, page 129).

Secondly, prisoners' insistence on equality and sameness can be seen as a pragmatic strategy to deal with shame and stigma (levins 2017; Ugelvik 2014b). This quote from the interview with Lone, where we talked about prisoners convicted of particularly serious offences, may serve as an illustration:

\section{Do you have any problems serving with people who have those type of problems?}

Not really. I do find it is awful that they have committed these crimes, if you think about it. [ ... ] You can't avoid thinking that, but if they are okay as a person and behave properly here and they are here to serve their sentence and get it over with, I try and have the attitude that we are all convicted of something and are therefore in the same boat. I try and stick to that philosophy (Lone, Bredtveit).

The insistence on equality and sameness, in this and many similar quotes in our study, is rather bold. It is bold because Lone compares herself with women who have committed far worse offences than she has, but still refrains from passing judgements because 'we are all convicted of something'. In a way, she is making herself just as bad as 'the worst'. One interpretation is that Lone, and others, refrain from passing judgements because they do not feel they are entitled to do so, having themselves committed punishable offences. Another interpretation is that the insistence on equality and sameness is a type of defense against the moral condemnation that lies at the heart of imprisonment (levins 2017). Many studies describe how stigmatized prison populations draw moral boundaries between themselves and others - between 'the rapist' and 'the proper criminal' (Ugelvik 2015), between 'crack heads' and 'hustlers' (Copes, Hochstetler \& Williams 2008) - thereby contributing to an increase in the amount and intensity of moral condemnation in prison. Our interviewees, by insisting on being equal and refraining from passing moral judgements, contributed to the opposite - they created 'low condemnation' environments.

A final aspect of 'pragmatic egalitarianism' concerns institutional risks and rewards. An important incentive to not bully, threaten or ostracise people based on convictions, behaviour or personalities - stems from a fear of losing privileges or being sanctioned. This is particularly so in open prisons, where engaging in this sort of behaviour would likely lead to a transfer to closed conditions in the high security estate, or losing the opportunity to be released on parole (Shammas 2015b). Dag explains:

No, because as soon as you do something like that here, then bang, straight into a closed prison immediately. And then you lose two-thirds [early release] immediately and then you have to serve the entire sentence (Dag, Bjørgvin).

Hence, prisoners do not only 'construct' sameness and withdraw from struggles over status and power in order to cope in prison everyday life; they may also do so simply to keep their privileges (Kreager et al. 2017; Shammas 2014). 
The pragmatic choices prisoners make about desisting from behaviour that challenges the 'egalitarian social order' of Norwegian prisons could thus be seen as a sign of legitimate and 'right' governance in these prisons (Sparks, Bottoms \& Hayes 1996). It is legitimate in the sense that the official prison governance is effective in preventing hierarchies, gangs and abusive prisoner led systems of (vertical) governance to develop (Skarbek 2020).

\section{Social labour}

Traditional accounts of social life in prison often portray prisoner hierarchies as relatively stable and static. We argue that sociality in the institutions in our study ought to be understood as much more fluid and volatile. A dynamic and circulatory (Scott 2011, page 53) social order, which required a considerable amount of pragmatism, flexibility, and compromise, characterized the prisons. Although the institutions we have studied appeared to be calm and our quotes show that prisoners largely felt safe, this does not mean that power was not continuously negotiated.

Hence, (re)producing friendliness and equality requires skill and finesse. Inspired by Jason Warr's development of the concept 'narrative labour', which he uses to describe the 'complex processes of evincing narrative acceptance in others' (Warr 2020, page 40), we use the concept of 'social labour' to describe the effort prisoners invest in creating socially bearable environments. One particularly apt illustration of these efforts is prisoners' descriptions of how tiring social life could be and how relieved they were when withdrawing to their cells (and rooms) at night:

[...] when they lock the door behind you and you are alone in your cell, how do you handle that time when you are left on your own and with your own thoughts?

I just relax. [ ... ] I think it's nice to get back to my cell. I have always felt that. It's not good to have everyone on top of you the whole time, so to speak. You do need a social aspect, it's not that, but I like it when I know the guards are going around for the last time in the evening and then it will be quiet after that. You can just relax and watch TV, even if it's boring (Mikkel, Arendal).

Mikkel described the dilemmas of social life in prison; you 'need a social aspect', but it is exhausting to have 'everyone on top of you' the whole time, which is a fitting image of how demanding it can be to live in close proximity with others, not of your own choosing. Similarly, Eigil (Bjørgvin) described how he felt like he could escape 'always having a lot of people around you' when he entered the cell at night to 'read or watch a film or listen to music or write a little bit'. Other interviewees were explicit about their own role in trying to 'improve the fellowship amongst the prisoners' (Ruben, Arendal) and how tiring that could be, which fostered a need to retreat to the cell. Life en masse (Sykes 1958) could surely be exhausting, even in open prisons, in the 
sense that 'there are people around you all the time. No matter where you go and where you are, you know' (Sindre, Bjørgvin). Importantly, the relief people described when withdrawing to their cells and rooms at night was not so much caused by living in constant fear during the day, or by having to wear 'a mask' and 'put up a front', but more so because prisoners were tired after a long day of 'social labour'.

While most of our interviewees benefited from their own and their fellow prisoners' social labour, some did not. Those who struggled with their mental illness, had learning disabilities or a highly stigmatised conviction could find it hard to fit in to an otherwise egalitarian sociality (Hammerlin 2008, page 570-571). The pro-social norms, although they stressed equality and sameness, could also lead to exclusion, where the people who failed to live up to these norms and ideals could be seen as strange or 'trouble-makers'. These prisoners were often either invisible, because they would stay in their cells or highly visible in the prison communities because they disturbed the calm order, and their behaviour was often deemed odd or antisocial. Tesfay's situation may illustrate the former. He served a long sentence for a sex offence conviction in an open prison, where staff worked hard to prevent peoples' convictions to be known and acted upon. One day, however, information about Tesfay's conviction started to spread between prisoners, and he suddenly found himself completely cut off from prison social life:

And I found out that people are talking with each other, so it makes me feel a bit alone. That I don't have any friends. So I go through my days and work out and stuff, just to pass the time. I work out alone but I used to, before, have some people I could work out with. But now I'm alone there (Tesfay, open prison).

A very loud, athletic and outspoken prisoner in a 'good behaviour' unit may serve to illustrate the latter. He was furious about the social norms of the unit, where everybody was expected to contribute to a good atmosphere:

They expect you to be happy, to smile. But if I have a bad day, I cannot smile. I will say it like it is: 'I have a bad day. Shit happens, that's the way it is'. But that is not popular in this place. It's impossible to be yourself in here. You have to smile, to please the officers. But I can't do that, that's not me. And I have to be who I am (fieldnotes, March 2017).

This prisoner used every opportunity to point out to us and others how much he despised the informal norms of civility at the unit, including having to act politely towards men convicted of sexual offences. However, his antagonistic attitude left him rather socially isolated in the unit, as the majority of men valued and actively participated in the institutionally prescribed social labour of the unit. 


\section{Conclusion}

We wish to summarise our findings and analysis by making three main points. The first is that we have described a social order in the prisons we studied that differs significantly from accounts in the literature. Our data contrast accounts where gang membership (Skarbek 2014), hegemonic masculinity (Jewkes 2005, Michalski 2017, Ugelvik 2014a,b), offence type (Treadwell et al. 2018) and involvement in the informal (drug) economy (Crewe 2005) are the main sources of social hierarchies in prison. We thereby add another perspective to 'accounts of prison life that have only sharp edges' (Laws \& Lieber 2020, page 3) by emphasising how social relationships were characterised by equality, connectivity, openness and decency. Relatedly, our findings problematize the idea that prison social life is inherently and inevitably based on (hegemonic masculine) hierarchies.

Our second point is that both permeability and pragmatism contribute to the egalitarian culture we have described in this article. Egalitarian orientations in Norwegian society seeps through the prison walls and contribute to a social order where prisoners insist on equality and sameness. Particularly, we find Sakslind and Skarpenes' argument about the significance of morality in Norwegian egalitarianism instructive. The 'moral orders' activated by our interviewees when refraining from passing judgments and referring to 'we are all in the same boat' do indeed resemble the "humility or modesty in forms of self-presentation, aligned with an egalitarianist rejection of vertical boundaries» that Sakslind and Skarpenes (2014, page 331) describe as a "generic trait» of Norwegian (class) culture. The 'permeability and porousness' (Shammas 2015b, page 5) of Norwegian open prisons - their minimal security arrangements and the flow of prisoners coming and leaving on relatively short sentences - help explain why egalitarian orientations are found within and not only outside Norwegian prison walls. However, we have also shown that social order was shaped by pragmatism to a large degree - life in these prisons ran smoother and became more bearable when everyone adhered to common decency. Similarly, the harder-edged threats of being transferred to a higher security level prison, losing privileges or jeopardizing parole if one failed to follow rules and norms, incentivized prisoners to treat each other with civility (see also Kreager et al. 2017). The pragmatic perspective on egalitarianism, as advocated by Gullestad, makes it possible to see how the prisoners' insistence on equality and sameness was also an adaptive strategy to deal with the pains of being confined with people not of your own choosing.

Our third point relates to the benefits of disrupting otherwise static and vertical depictions of moral hierarchies in prison in favor of a more circulatory (Scott 2011) and dynamic portrayal of social life. The findings presented in this article show that 'traditional' prisoner hierarchies were eschewed and to a larger extent based on 'likability', friendliness and abilities to adapt rather than offense type, sentence length or involvement in the informal prison economy. 
This led prison social life to be characterised more by 'horizontal harmony' than 'vertical antagonism'. Importantly, by not considering what other prisoners' convictions morally communicate about who they are and by insisting on being equal and 'denying difference' (Shammas 2015a), our interviewees often managed to create 'low condemnation' environments in the prisons we studied.

Although we do not aim to disavow the presence of anger, aggression and violence in Norwegian prisons, we mostly saw an 'ethos of cooperation rather than coercion' (O'Donnell 2019, page 3). Virtues such as respect, sociability and equality were highly rated social lubricants (Laws \& Lieber 2020, page 14), which helped create dynamic and supportive social relationships, particularly in the open wings and units we studied. In order to capture this 'ordinariness' of social life in many Norwegian prisons - the degree to which it resembles social life in communities outside prison - the term 'relational normality' might hold some promise. The concept builds on the 'principle of normality' by highlighting its relational dimension - the sense that social norms, behaviours and dynamics in these prisons are not that different from those found in the community. This might prove to be a useful concept to understand and conceptualise the degree to which the relational qualities of a prison reduce or produce pain.

Kontaktoplysninger

Kristian Mjåland: kristian.mjaland@uia.no

Julie Laursen: j1862@cam.ac.uk

\section{References}

Baer, LD \& Ravneberg, B (2008) The outside and inside in Norwegian and English prisons. Geografiska Annaler 90(2): 205-216. https://doi.org/10.1111/j.1468-0467.2008.00287.x

Balvig, F (2005) When Law and Order Returned to Denmark, Nordic Journal of Criminology, 5(2): 167-187.

https://doi.org/10.1080/14043850410010711

Bendixen, S, Bringslid, M B and Vike, H (2018) Egalitarianism in Scandinavia: Historical and Contemporary Perspectives, Cham: Palgrave Macmillan. https://doi.org/10.1007/978-3-319-59791-1

Blaikie, N (2000) Designing social research: the logic of anticipation. Cambridge: Polity Press.

Cohen, S \& Taylor, L (1972) Psychological survival: the experience of long-term imprisonment. Harmondsworth: Penguin.

Copes, H, Hochstetler, A and Williams, J P (2008) «We Weren't Like No Regular Dope Fiends»: Negotiating Hustler and Crackhead Identities. Social Problems, 55(2): 254-270. https://doi.org/10.1525/sp.2008.55.2.254

Crewe, B (2005) Prisoner society in the era of hard drugs. Punishment \& Society, 7(4): 457-481. https://doi.org/10.1177/1462474505057122

- (2011) Depth, weight, tightness: Revisiting the pains of imprisonment. Punishment \& Society 13(5): 509-529.

https://doi.org/10.1177/1462474511422172 
- (2014) 'Not Looking Hard Enough: Masculinity, Emotion, and Prison Research', Qualitative Inquiry, 20(4), pp. 392-403. https://doi.org/10.1177/1077800413515829

Crewe, B, Hulley, S and Wright, S (2020) Life Imprisonment from Young Adulthood: Adaptation, Identity and Time. London: Palgrave Macmillan. https://doi.org/10.1057/978-1-137-56601-0

de Viggiani, N. (2012) 'Trying to be Something You Are Not: Masculine Performances within a Prison Setting', Men and Masculinities, 15(3), pp. 271-291.

https://doi.org/10.1177/1097184X12448464

Engbo, H J (2017) Normalisation in Nordic Prisons - From a Prison Governor's Perspective. In Smith, PS \& Ugelvik, T (eds) Scandinavian Penal History, Culture and Prison Practice: Embraced By the Welfare State? Palgrave Macmillan, 327-352. https://doi.org/10.1057/978-1-137-58529-5_14

Engbo, H J og Smith, P S (2012) Fængsler og menneskerettigheder. DJØF.

Evans, T \& Wallace, P (2008) A prison within a prison? The masculinity narratives of male prisoners. Men and Masculinities 10(4): 484-507. https://doi.org/10.1177/1097184X06291903

Goffman, E (1961) Asylums. Anchor Books.

Gullestad, M (1984) Kitchen-table Society. Oslo/Oxford: Scandinavian University Press

Haller, M B \& Kolind, T (2018) Space and ethnic identification in a Danish prison. Punishment \& Society, 20(5): 580-598. https://doi.org/10.1177/1462474517722541

Hammerlin, Y (2008) Om fangebehandling, fange- og menneskesyn i norsk kriminalomsorg i anstalt 1970-2007. PhD Dissertation. University of Oslo: Faculty of Law.

Levins, A (2017) Adaptation, Moral Community and Power in a Prison for Men Convicted of Sex Offences. PhD Dissertation. University of Cambridge: Institute of Criminology.

Jewkes, Y (2005) Men behind bars: 'Doing' masculinity as an adaptation to imprisonment. Men and Masculinities 8(1): 44-63. https://doi.org/10.1177/1097184X03257452

Kreager, D, Young, J T N, Haynie, D L, Bouchard, M, Schaefer, D R and Zajac, G (2017) Where "Old Heads» Prevail: Inmate Hierarchy in a Men's Prison Unit. American Sociological Review, 82(4): 685-718. https://doi.org/10.1177/0003122417710462

Kriminalomsorgen (2020) Årsstatistikk 2019. Kriminalomsorgsdirektoratet (KDI) 11/2020.

Lappi-Säppäla, T (2020) Penal transformations in the Nordics. Keynote presentation at the conference 'Nordic Punishment at a Crossroads?', University of Oslo, 11-12 March.

Laursen, J (2017) (No) Laughing Allowed - Humour and the Limits of Soft Power in Prison, British Journal of Criminology, 57 (6): 1340-1358.

Laws, B \& Lieber, E (2020) 'King, Warrior, Magician, Lover': Understanding expressions of care among male prisoners. European Journal of Criminology. https://doi.org/10.1177/1477370819896207

Lindberg, $\bigcirc$ (2005) Prison cultures and social representations: The case of Hinseberg, a women's prison in Sweden. International Journal of Prisoner Health, 1(2/3/4): 143-161. https://doi.org/10.1080/17449200600553076

Mathiassen, C (2017) Being a women in mixed-gender prisons. In Smith, PS \& Ugelvik, T (eds) Scandinavian Penal History, Culture and Prison Practice: Embraced By the Welfare State? Palgrave Macmillan, 377-404.

https://doi.org/10.1057/978-1-137-58529-5_16

Michalski, J H (2017) Status Hierarchies and Hegemonic Masculinity: A General Theory of Prison Violence, British Journal of Criminology, 57(1): 40-60. https://doi.org/10.1093/bjc/azv098

Minke, L K (2012) Fængslets indre liv. Jurist og Økonomforbundets Forlag.

- (2014) A Study of Prisonization among Danish Prisoners, Prison Service Journal, 211: 37-42. 
Mjåland, K (2014) 'A culture of sharing': Drug exchange in a Norwegian prison, Punishment \& Society, 16(3): 336-352.

https://doi.org/10.1177/1462474514527149

O'Donnell, I (2019) The society of captives in an Ethiopian prison. Prison Journal 99(3): 267-284.

https://doi.org/10.1177/0032885519836947

Pratt, J (2008) Scandinavian Exceptionalism in an Era of Penal Excess: Part I: The Nature and Roots of Scandinavian Exceptionalism, The British Journal of Criminology, 48 (2): 119-137. https://doi.org/10.1093/bjc/azm072

Pratt, J \& Eriksson, A (2013) Contrasts in Punishment: An explanation of Anglophone excess and Nordic exceptionalism. London: Routledge. https://doi.org/10.4324/9780203096116

Sakslind, R and Skarpenes, O (2014) Morality and the Middle Class: The European Pattern and the Norwegian Singularity. Journal of Social History, 48(2): 313-340. https://doi.org/10.1093/jsh/shu074

Sakslind, R, Skarpenes, $O$ and Hestholm, R (2018) Middelklassekulturen i Norge: En komparativ sosiologisk studie. Oslo: Scandinavian Academic Press.

Scott, S (2011) Total institutions and reinvented identities. New York: Palgrave MacMillan. https://doi.org/10.1057/9780230348608

Shammas, VL (2014) The pains of freedom: Assessing the ambiguity of Scandinavian penal exceptionalism on Norway's Prison Island. Punishment \& Society 16(1): 104-123. https://doi.org/10.1177/1462474513504799

- (2015a) Denying the danger of difference: Notes on the pacification of inmate social relations in an era of ethnoracial diversity. Prison Service Journal, 219: 5-10.

- (2015b) A prison without walls: Alternative incarceration in the late age of social democracy, Prison Service Journal, 217: 3-9

Sim, J (1994) «Tougher than the Rest? Men in Prison.» In Just Boys Doing Business? Men, Masculinities, and Crime, edited by Newburn, J., Stanko, E. A., 100-17. London, UK: Routledge.

Skarbek, D (2014) The Social Order of the Underworld: How Prison Gangs Govern the American Penal System. Oxford University Press.

https://doi.org/10.1093/acprof:oso/9780199328499.001.0001

- (2020) The Puzzle of Prison Order: Why Life Behind Bars Varies around the World. Oxford University Press.

Skarpenes, O \& Sakslind, R (2010) Education and Egalitarianism: The Culture of the Norwegian Middle Class. The Sociological Review, 58 (2): 219-243. https://doi.org/10.1111/j.1467-954X.2010.01901.x

Skarpenes, $\bigcirc$ (2021) Defending the Nordic model: Understanding the moral universe of the Norwegian working class. European Journal of Cultural and Political Sociology. https://doi.org/10.1080/23254823.2021.1895857

Smith, PS \& Ugelvik, T (eds.) (2017) Scandinavian Penal History, Culture and Prison Practice: Embraced By the Welfare State?. Palgrave Macmillan.

Sparks, T, Bottoms, AE \& Hayes, W (1996) Prisons and the Problem of Order. Clarendon. https://doi.org/10.1093/acprof:oso/9780198258186.001.0001

Stevens, A (2013) Offender Rehabilitation and Therapeutic Communities: Enabling Change the TC Way. London and New York: Routledge.

https://doi.org/10.4324/9780203101124

Swidler, A (1986) Culture in Action: Symbols and Strategies. American Sociological Review, 51(2): 273-286.

https://doi.org/10.2307/2095521

Sykes, G (1958) The Society of Captives. Princeton, NJ: Princeton University Press. 
Toch, H (1998) Hypermasculinity and prison violence. In: Bowker, HL (ed.) Masculinities and Violence. Thousand Oaks, CA: Sage Publications, 168-178. https://doi.org/10.4135/9781483328010.n9

Treadwell, J, Gooch, K \& Barkham-Perry, G 2018, 'Crime in Prison: What now and where next?'

Ugelvik, T (2014a) 'Be a man. Not a bitch.' Snitching, the inmate code and the narrative reconstruction of masculinity in a Norwegian prison. In Lander, I; Ravn, S \& Jon, N (eds.), Masculinities in the Criminological Field. Ashgate.

- (2014b) Power and Resistance in Prison: Doing Time, Doing Freedom. Palgrave Macmillan.

- (2015) The Rapist and the Proper Criminal: The Exclusion of Immoral Others as Narrative Work on the Self. In Presser, L \& Sandberg, S (eds) Narrative Criminology: Understanding Stories of Crime. New York: New York University Press, 23-41.

Ugelvik, T \& Dullum, J (eds.) (2012). Penal Exceptionalism?: Nordic prison policy and practice. Routledge.

https://doi.org/10.4324/9780203813270

Warr, J (2020) 'Always gotta be two mans': Lifers, risk, rehabilitation, and narrative labour. Punishment \& Society, 22 (1): 28-47. https://doi.org/10.1177/1462474518822487 